\title{
Using the Fuzzy Delphi Method to Apply a Model of Knowledge Transfer through International Strategic Alliances in Up-Stream Oil and Gas Sectors
}

\author{
Salman Kimiagari \\ Laval University \\ E-Mail: salman.kimiagari@cirrelt.ca \\ Samira Keivanpour \\ Laval University \\ E-Mail: samira.keivanpour@cirrelt.ca \\ Md. Samim Al-Azad \\ Seoul National University \\ E-Mail: samim@snu.ac.kr \\ Muhammad Mohiuddin \\ Thompson Rivers University \\ E-Mail: mmohiuddin@tru.ca
}

\begin{abstract}
The upstream petroleum industry includes associated service businesses such as seismic and drilling contractors, service rig operators, engineering firms and various scientific, technical service and supply companies. These extremely high-tech activities require the continuous inflow of knowledge and technologies for reconfiguring and rebuilding capabilities that fit with the continuous changes in the marketplace for sustaining a competitive advantage. To that end, infrastructures and policy orientations are required to create a conducive environment for knowledge transfer (KT) to enhance knowledge capability. This paper aims to explore how strategic alliances lead to KT that enhances organizational capabilities. We analyze the case of the National Iranian Oil Company (NIOC) to test the fuzzy Delphi model (FDM) framework. We develop a conceptual framework establishing the link between the strategic alliances (SA) and their facilitators for developing the knowledge
\end{abstract}


capabilities of upstream oil and gas companies. We tested the proposed model using FDM to show how international strategic alliances (ISA) in the upstream oil and gas sector transfer knowledge and have positive effects on developing the NIOC's knowledge capability. Positive outcomes include knowledge acquisition from partners, developing knowledge management techniques and facilitating the implementation of knowledge-based structure, developing high-tech production and exploration methods, increasing investment in innovation, and developing human resources and information technology uses.

Keywords: Knowledge Transfer, Upstream Oil and Gas Sector, International Strategic Alliances, Emerging Countries

\section{INTRODUCTION}

Strategic alliances are considered an effective mechanism for reducing costs and mitigating risks for partners. They have grown exponentially in recent years, especially following the financial crises (Karuranga, Asti, Musonera, \& Mohiuddin, 2010) and are now a very popular instrument for global market competition. Many of the world's largest companies have more than $20 \%$ of their assets and more than $30 \%$ of their annual research expenditures under an alliance framework (Ernst \& Bamford, 2005). More than $80 \%$ of Fortune 1000 CEOs believe that such alliances accounted for almost $26 \%$ of their companies' revenues in 2007-08 (Kale, Singh, \& Bell, 2009). Recent contextual and environmental changes in the marketplace have created intense competitions that require rigorous knowledge management for continuous capability development to achieve a competitive advantage. The formation of an alliance among firms can enhance knowledge transfer and knowledge absorptive capacity for organizational capability building. Moreover, the formation of inter-firm alliances is a global phenomenon in almost all industries in the era of alliance capitalism (Contractor \& Lorange, 2002). Through social interactions between partners, alliances serve as a platform for knowledge creation and/or learning (Al-Azad, Mohiuddin, \& Rashid, 2010). As partners jointly manage efforts and collaborate, opportunities to learn from each other naturally arise. Therefore, ISA can be considered as a mechanism to develop knowledge capital that helps organizations survive in today's competitive business atmosphere. The oil and gas industry is the backbone of any industrialization, yet the market is volatile and needs continuous development of the capabilities for extracting these resources from increasingly tough terrain, such as shale gas. Strategic alliances can bring together several firms and create economy of scale for their capabilities as well as coordinate their complementary capabilities. The 
trade embargo and relative isolation of the National Iranian Oil Company (NIOC) hinder its ability to benefit from strategic alliances. The current paper thus studies the possibility of capability development via knowledge transfer through international strategic alliances (ISAs) between the NIOC and international oil companies (IOCs), as such ISAs can create a conductive environment for knowledge transfer (KT) and learning among the contracting partners and lead to movement up the value ladder (Mohiuddin \& Su, 2014).

Despite an increasing amount of literature on KT, few studies address this topic in the oil and gas industry. These studies focus on the knowledge management mechanism (Carrillo \& Chinowsky, 2006) or one aspect of KT, technology issues, (Managi et al., 2005), or the role of the knowledge in the industry (Sasson \& Blomgren, 2011). Considering the role of ISAs between NIOC and IOCs, evaluating the outcomes of KT in the partnership agreements is essential. A framework for addressing the leverages of KT in enhancing knowledge capabilities can be a valuable tool for state-owned organizations and policy makers. In this paper, we introduce a conceptual framework to demonstrate the link among ISAs in the upstream oil and gas sector and their role in developing knowledge and capability for the partner companies.

Hence, the objective of the paper is to highlight the link between ISAs and knowledge transfer as well as the capability development in the oil and gas industry. In order to provide an experimental study, we focused on NIOC, the second largest oil and gas company in the world. A corporate strategic alliance between the NIOC and IOCs has a strong potential for developing the NIOC's knowledge capability and enabling it to become competitive in the marketplace.

\section{ISA AND KT IN UPSTREAM OIL AND GAS INDUSTRY}

Strategic alliances are a type of collaboration among two or more companies that have the potential to create more value than the associative value of the individual alliance partner. In ISAs, alliance partners establish a joint agreement through which they carry out their joint projects with shared resources (Hagedoorn \& Sadowski, 1999). Therefore, ISAs are considered a means of value creation. Establishing a successful network structure in a multicultural context requires assessing different aspects of strategic alliances. It also involves reviewing the nature of strategic relationships and forming these international alliances to understand how they create successful partnerships. Transaction cost theorists argue that the level of environmental ambiguity on a transaction determines the choice of mergers and alliances (M\&A) versus alliances only. In relatively efficient markets, either M\&A or 
alliances are needed, but market imperfections raise the costs of transactions, and alternatives to market transactions must then be considered (Williamson, 1985). Resource-based views of the firm (Eisenhardt \& Schoonhoven, 1996) assert that alliances between firms, compared to M\&A, can be used as a less expensive and more elastic mechanism to support cooperation and knowledge transfer. Strategic alliances allow firms to gain access to complementary factors of production across multiple business units and firms, thereby leading to production-side synergies, economies of capacity and improved firm activities (Davis \& Thomas, 1993; Mohiuddin \& Su, 2013). Dehkordi et al. (2014) studied the technology transfer strategy of the petrochemical process to Iranian industries and concluded that establishing a joint venture with an international company with the technological know-how and strong experience in technology in demand can help companies succeed in their investments. Grant (2013) reviewed the knowledge management practices in reputed IOCs such as BP, Royal Dutch Shell, Chevron, ExxonMobil, ConocoPhillips, Halliburton, Schlumberger, and Paragon Engineering Services and identified two main types of knowledge management practices: "applications of information and communications technology to the management of explicit knowledge and the use of person-to-person knowledge management techniques to facilitate the transfer of tacit knowledge" ( $p$. 93). Grant's study also mentioned the challenges of transforming tacit into explicit knowledge and the importance of knowledge management initiatives. With respect to the benefits of establishing the alliances, companies across various industries have applied this approach in order to achieve the outstanding outcomes of strategic alliances. Table 1 shows outcomes of alliances in different industries. These outcomes can be studied in the context of intellectual capital, learning organizations and knowledge management.

According to the United Nations Country Readiness Assessment report (2002), a knowledge-based economy has a very influential technological dynamic force. Moreover, knowledge - based on information and reinforced by cultural and spiritual values - has become an independent force and the most critical factor of social, economic, technological and cultural transformation. Enhanced collaborations among the firms and countries facilitate knowledge transfer or knowledge exchanges and further develop the knowledge bases and various applications of existing knowledge through recombining, reconfiguring and remodeling. Such collaborations can be very advantageous for firms from emerging countries, such as the NIOC, by integrating with IOCs' intellectual pool. Hence, developing human capital, knowledge and knowhow as well as a framework for building knowledge capital can be considered the core elements of exchanges under an ISA framework. 
Table 1 The strategic Alliances in Different Industries and Outcomes

\begin{tabular}{|c|c|c|c|}
\hline Studies & Industries & Type of relationship & Outcome \\
\hline Chew (2006) & $\begin{array}{l}\text { Malaysian high-tech } \\
\text { industries }\end{array}$ & $\begin{array}{l}\text { Licensing, } \\
\text { Franchising, Joint } \\
\text { venture, Turnkey } \\
\text { Project, FDI }\end{array}$ & $\begin{array}{l}\text { High rate of } \\
\text { technology transfer }\end{array}$ \\
\hline $\begin{array}{l}\text { Ernst \& Steinhubl } \\
\text { (1997) }\end{array}$ & $\begin{array}{l}\text { Upstream oil and gas } \\
\text { in North America }\end{array}$ & Alliances & $\begin{array}{l}\text { An opportunity to } \\
\text { improve } \\
\text { performance, a way } \\
\text { to build strengths and } \\
\text { leading in market } \\
\text { position }\end{array}$ \\
\hline $\begin{array}{l}\text { Aigboduwa\& } \\
\text { Oisamoje (2013) }\end{array}$ & $\begin{array}{l}\text { Nigerian Oil and Gas } \\
\text { Industry }\end{array}$ & Joint ventures & $\begin{array}{l}\text { Employment } \\
\text { generation and wealth } \\
\text { creation via SME }\end{array}$ \\
\hline Baldi (2013) & $\begin{array}{l}\text { Oil industry in } \\
\text { Venezuela }\end{array}$ & Strategic alliances & $\begin{array}{l}\text { The opportunity of } \\
\text { sharing knowledge } \\
\text { and expertise in } \\
\text { upstream operations }\end{array}$ \\
\hline $\begin{array}{l}\text { Jegede, Ilori, } \\
\text { Sonibare, } \\
\text { Oluwale, \& } \\
\text { Siyanbola (2013) }\end{array}$ & $\begin{array}{l}\text { Oil and Gas Industry } \\
\text { in Nigeria }\end{array}$ & $\begin{array}{l}\text { Joint ventures, } \\
\text { cooperative } \\
\text { enterprises or new } \\
\text { limited liability } \\
\text { firms as a solution } \\
\text { for development } \\
\end{array}$ & $\begin{array}{l}\text { Knowledge Sharing } \\
\text { and Innovation }\end{array}$ \\
\hline $\begin{array}{l}\text { Carayannis, } \\
\text { Alexander, \& } \\
\text { Ioannidis (2000) }\end{array}$ & $\begin{array}{l}\text { Government- } \\
\text { university-industry } \\
\text { (GUI) R\&D } \\
\text { partnerships in the } \\
\text { US, Germany, and } \\
\text { France }\end{array}$ & Strategic alliances & $\begin{array}{l}\text { Leveraging } \\
\text { knowledge, learning, } \\
\text { and innovation }\end{array}$ \\
\hline
\end{tabular}

\section{CONCEPTUAL FRAMEWORK}

Figure 1 shows the conceptual framework by linking the important approaches of strategic alliance formation in today's global economy.

In the following sections, we explain the principal components and relationships of different items of our conceptual framework.

Appropriate Partner Selection and Effective AgreementPartner selection is an important decision firms make when forming strategic alliances because the choice of a partner will drive the general combination of available skills and resources, the operating policies and procedures, and long-term viability (Geringer, 1991) of an alliance. Appropriate partner selection could avoid position conflicts and decrease the 
traditional threats involving alliance partners, such as management and coordination disagreements, instability (Hennart \& Larimo, 1998), and incongruent objectives. Significant numbers of alliances fail as a business strategy even when their popularity prevails in most business sectors (Lee \& Cavusgil, 2006). One of the most often-cited reasons for this is partners' incompatibility, leading to alliance failure. Hence, the choice of the right partner can lead to important competitive benefits. Lee and Cavusgil (2006) found that the choice of an appropriate partner for strategic alliance is an important factor affecting alliance performance in the logistics value chain. Finding the exact partner requires careful screening and can be a time-consuming process. One of the first and most comprehensive studies of partner selection criteria was conducted by Geringer (1988). He found that a partner's culture, past experience, size, and structure are as important in partner selection as task-related criteria, such as partners' technical know-how, financial assets, managerial experience, and access to markets. Based on detailed literature reviews (Das \& Teng, 2000; Hafeez, Malak, \& Zhang, 2007; Kumar \& Malegeant, 2006), two groups of evaluation criteria have been defined; these authors subsequently used these criteria in each of their proposed frameworks. The first group of evaluation criteria focuses on the strategic aspects of collaboration and identifies them as similar values and goals, size, financial stability, culture, track record, and fit to develop a sustainable relationship. The next group of evaluation criteria was developed to assess vital aspects of the partner's business in four major groups: partners' technical know-how, partners' performance, partners' value, and executive experience.After the partner selection process, the negotiation and agreement framework is an important step for establishing strategic alliances. The accountability and responsibility of senior management, the clear definition of individuals' roles within the alliance and totally explicit agreement from formation to termination are considered to demonstrate effective agreement (Devlin \& Bleackley, 1988).

\section{Alliance Management and Performance}

Thus far, most inter-organizational collaboration research has focused on the revelation or prescription of antecedent factors and parameters that are likely to induce successful alliances (Child \& Faulkner, 1998). Studies exploring the role of organizational learning and organizational commitments in achieving superior performance in international alliances are infrequent (Das \& Teng, 2000). These studies have revealed that organizations that exploit learning opportunities and involve 
continuous learning are likely to be more adept at achieving positive performance outcomes from their partnerships (Gnyavali \& Grant, 1997). However, there is unanimous opinion regarding how we can measure such performance (Glaister \& Buckley, 1999). The establishment of learning and performance in ISA has been grounded in, and thus emerged from, the extant literature in organizational learning (Sinkula, 1994), learning orientation (Sinkula, Baker, \& Noordewier, 1997), organizational commitment (Reichers, 1985), the resource-based and social exchange theories of the firm (Das \& Teng, 2000), and the evolutionary perspective on alliance learning (Iyer, 2002). Emden et al. (2005) argued that learning from previous practices is an effective way to ease coordination challenges and, thus, is a key factor for improving a firm's alliance performance. They also discussed that learning from experiences is an essential factor creating higher performance for the firm by facilitating inter-firm know-how transfers.

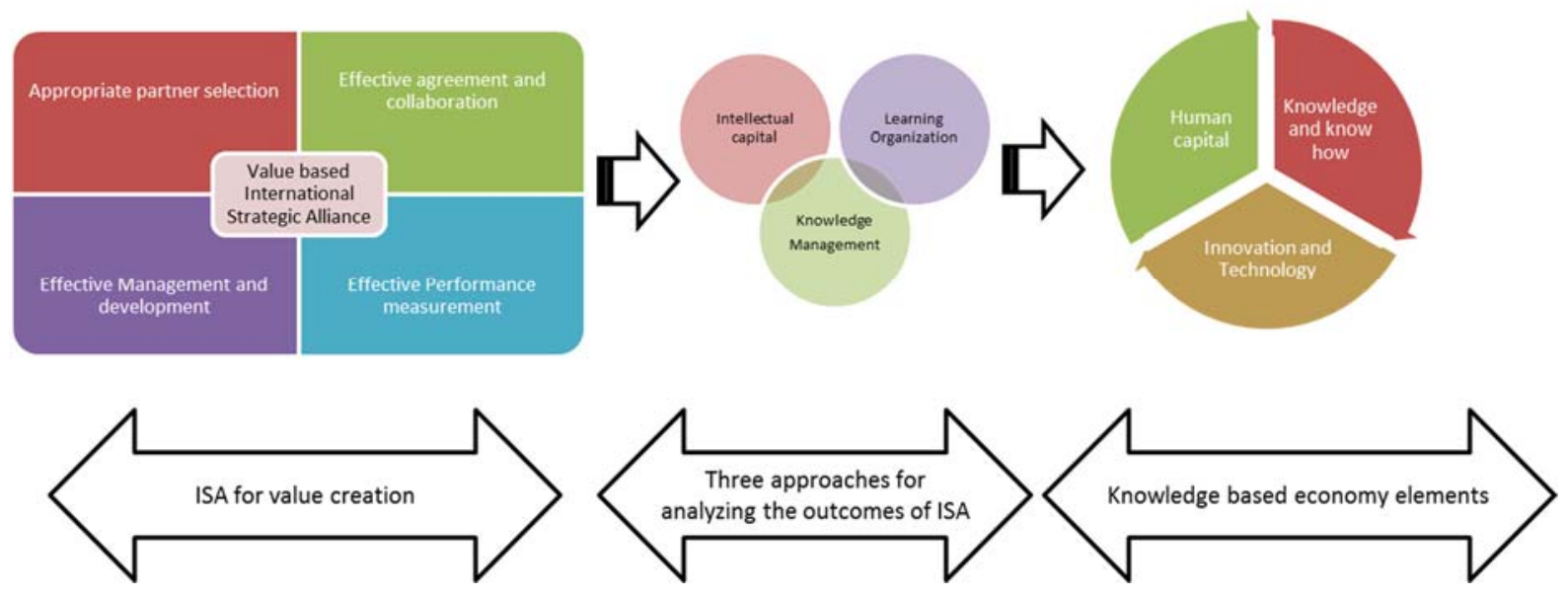

Figure 1: Proposed Conceptual Model

\section{Three Principal Outcomes of ISA}

Three basic concepts of a learning organization link to the new paradigm in ISA: people aspire to expand knowledge and learning (Senge, 1990), the organization facilitates learning for its members (Pedlar, 1991), and people are involved in sharing knowledge (Watkins \& Marsick, 1992). Table 2 highlights these three approaches in the strategic alliance context. 
Table 2 Three Outstanding Outcomes of ISA

\begin{tabular}{|c|c|c|}
\hline $\begin{array}{l}\text { Three } \\
\text { approaches }\end{array}$ & Source & Relationship \\
\hline \multirow[t]{2}{*}{$\begin{array}{l}\text { Intellectual } \\
\text { capital }\end{array}$} & $\begin{array}{l}\text { Hussi, 2004; } \\
\text { Hermans \& } \\
\text { Kauranen, } 2005 \\
\end{array}$ & $\begin{array}{l}\text { Dealing with uncertainty and complexity } \\
\text { involved in inter-firm collaborations. }\end{array}$ \\
\hline & Powell et al, 1996 & Forming social networks with external parties \\
\hline \multirow{3}{*}{$\begin{array}{l}\text { Learning } \\
\text { Organization }\end{array}$} & $\begin{array}{l}\text { Kotabe \& Swan, } \\
1995\end{array}$ & $\begin{array}{l}\text { Firms with stronger learning capability are } \\
\text { thought to be more capable of using this } \\
\text { platform to gain tacit benefits, sustain } \\
\text { competitiveness, and excel in market and } \\
\text { financial performance. }\end{array}$ \\
\hline & $\begin{array}{l}\text { Lane, Salk, \& } \\
\text { Lyles, } 2001\end{array}$ & $\begin{array}{l}\text { Learning capability is thought to benefit firm } \\
\text { performance. }\end{array}$ \\
\hline & $\begin{array}{l}\text { Kale, Singh, \& } \\
\text { Perlmutter, } 2000\end{array}$ & $\begin{array}{l}\text { Learning from partners and the frameworks for } \\
\text { knowledge acquisition }\end{array}$ \\
\hline \multirow{5}{*}{$\begin{array}{l}\text { Knowledge } \\
\text { management }\end{array}$} & $\begin{array}{l}\text { Khamseh \& Jolly, } \\
2008\end{array}$ & $\begin{array}{l}\text { Knowledge-based activities are at the basis of } \\
\text { sustainable competitive advantage in today's } \\
\text { economy }\end{array}$ \\
\hline & $\begin{array}{l}\text { Kiessling, Richey, } \\
\text { Meng, \& Dabic, } \\
2009\end{array}$ & $\begin{array}{l}\text { Knowledge management positively affects } \\
\text { organizational outcomes of firm innovation, } \\
\text { product improvement and employee } \\
\text { improvement }\end{array}$ \\
\hline & $\begin{array}{l}\text { Anand \& Khanna, } \\
2000 ; \text { Nielsen, } \\
2005\end{array}$ & $\begin{array}{l}\text { The role of knowledge as the source of } \\
\text { competitive advantage which clarifies the role } \\
\text { of effective management of inter-firms } \\
\text { knowledge }\end{array}$ \\
\hline & $\begin{array}{l}\text { Cohen \& } \\
\text { Levinthal, 1990; } \\
\text { Lyles \& Salk, } 1996\end{array}$ & $\begin{array}{l}\text { Knowledge absorption, which emphasizes the } \\
\text { capacity of organizations for knowledge } \\
\text { transferring }\end{array}$ \\
\hline & $\begin{array}{l}\text { Nielsen }(2005) \text {; } \\
\text { Anand \& Khanna } \\
(2000)\end{array}$ & $\begin{array}{l}\text { The role of knowledge as the source of } \\
\text { competitive advantage which clarifies the role } \\
\text { of effective management of inter-firms } \\
\text { knowledge }\end{array}$ \\
\hline
\end{tabular}

\section{Knowledge Transfer for Knowledge Capabilities}

Rich literature addresses the knowledge management process, different types of knowledge, knowledge creation and transfer through different channels, such as collaboration links, partnerships and efforts within the organizations (Davenport \& 
Prusak, 1998; Nonaka \& Takeuchi, 1995; Badaracco, 1991). Two specific types of knowledge are identified in the literature: tacit knowledge and explicit knowledge. The mechanisms for the transferral, management and codification of these two types are different and challenging issues (Nonaka \& Takeuchi, 1995). Tacit knowledge is personal; it is difficult to codify and transfer to others. Meanwhile, explicit knowledge is what is recorded in an organized way, such as manual, procedures or reports (Hansen et al., 1999). In this study, knowledge refers to both types of knowledge: tacit knowledge that can be transferred via meetings, teamwork activities and other interactions between partners and explicit knowledge that refers to systematic procedures, reports and manuals provided during the project execution of ISAs' joint agreement. According to Chen and Huang (2009), innovation creates the motivating force behind an enterprise's development and contributes to knowledge. However, $R \& D$ requires enormous amounts of capital; in relation to this, the enterprise also needs to accept tremendous risks. In order to split up the risk, enterprises endeavour to remain competitive, either through strategic alliances or through alliances between different businesses as well as horizontal cooperation and joint $\mathrm{R} \& \mathrm{D}$, or by stipulating product standards and means of production (Huang \& Chen, 2004, p. 179). Knowledge transfer studies have long advocated that, through effective knowledge transfer, the knowledge re-user acquires short-term gains such as (i) reproducing superior results obtained by the source and (ii) saving time and costs by avoiding redundant trials and errors (Hansen, 1999). What is implicitly assumed by "successful" knowledge transfer is that the re-user absorbs the source's knowledge during the transfer process and becomes capable of fully utilizing it (Cohen \& Levinthal, 1990). In the context of the NIOC, it has lots to gain from ISAs and can develop its knowledge capability for competing in competitive and strategic marketplaces such as the upstream oil and gas industry.

The OECD's (2002) key policy recommendations concerning the management and development of knowledge include strengthening economic and social fundamentals, facilitating the diffusion of ICT, fostering innovation, investing in human capital and stimulating firm creation (Kriščiūnas \& Daugèlienè, 2006). ISAs between IOCs and the NIOC can certainly make important contributions to this process. Based on these policies and characteristics of knowledge creation (Kriščiūnas \& Daugèlienè, 2006), we selected human capital, innovation and technology and knowledge as the three key elements in knowledge transfer under the ISA framework between IOCs and the NIOC. 


\section{APPLICATION OF FUZZY DELPHI METHOD TO PROPOSED FRAMEWORK}

We use the fuzzy Delphi method (FDM) to evaluate the conceptual framework. The FDM, introduced by Ishikawa et al. (1993), is a combination of traditional Delphi technique and fuzzy set theory. With respect to the uncertainty about the judgment of decision makers and the nature of linguistic variables, the fuzzy set theory considers an appropriate approach for this study. The Delphi technique can be conducted in writing and does not need face-to-face meetings. It also helps generate consensus or recognize the deviation of opinions between groups challenging each other. Moreover, it helps to remain focused on the subject and allows a number of experts to be called upon to give a broad scope of views (Turoff \& Linstone, 2002). The framework was tested through a Delphi process involving an international panel of more than five researchers and practitioners. The experts were three faculty members from the management department at Tehran University as well as two industry experts who are senior managers in the NIOC and in charge of strategic negotiations with IOCs. The NIOC's top managers recommended the experts in this study. The Delphi process involved two rounds of analysis and assessment by the panel of experts. Each of the Delphi's iterations involved answering questions assessing the framework with respect to the three criteria-clarity, comprehensiveness and completeness-while incorporating adjustments to address panelists' comments. The Delphi methodology used here is similar to that used by Bacon and Fitzgerald (1996) in developing an information technology framework. A questionnaire was designed to elicit comments on the framework (i.e., its comprehensiveness, clarity, and completeness). The questionnaire was pilot tested, and the feedback was used to refine its content. The final instrument consisted of both open-ended questions for structured elicitation and Likert-scale items; a 5-point scale (ranging from "not at all good" to "extremely good") was used. After collecting evaluators' opinions, we used a triangular fuzzy number of each alternate factor given by experts. Hence, for each element of the conceptual framework, we have a fuzzy number allocated by each expert. We then calculated the minimum, maximum and average of the five evaluations for each element. After this step, we defuzzified these numbers using a simple center of gravity method to defuzzify the fuzzy weight for each element. We then kept those elements with an evaluation index greater than 3 in the model and deleted those elements with an evaluation index lower than 3 . 


\section{RESULTS AND DISCUSSIONS}

In round 1, we confirmed and modified the overall framework of the model and focused on the meaningfulness of the parameters of the model's structure. In this round, some of the experts' questions were addressed and the topic was further explored to improve our understanding. In round 2 , the feedback from round 1 was reviewed by the experts to assess the degree of the clarity, completeness and comprehensiveness of the model. No fundamental changes or concerns emerged regarding panelists' responses from round 1, and we added some more explanations for better comprehension. Some experts asked questions regarding areas of concern in ISA sections that were considered to be acceptable factors after some explanation, such as what level of knowledge management has been considered? Information technology has already been considered in knowledge management because knowledge management without specific and appropriate information technology cannot be realized. ISAs' structure and agreement are broad concepts and should be addressed precisely. Panelists quantitatively evaluated the framework in terms of the three criteria. Graphical displays of participants' responses to Likert-scale items in the second round are presented in the figures. All respondents rated the framework as being at least somewhat successful on all criteria. For every criterion, a preponderance of respondents rated the framework as at least moderately good.

Table 3 shows the results of the evaluation. The majority of respondents assessed the framework's accuracy and clarity to be in the moderately good to extremely good range.

Table 3 Conceptual Model Evaluation Results

\begin{tabular}{llllc}
\hline The elements of conceptual framework & Min & Average & Max & De-Fuzzy \\
\hline ISA for value creation & & & & \\
Appropriate partner selection & 2 & 3,4 & 5 & 3,46 \\
Clarity & 2 & 3,4 & 5 & 3,46 \\
Comprehensiveness & 2 & 3,4 & 5 & 3,46 \\
Completeness & 2 & 3,4 & 5 & 3,46 \\
Effective agreement and collaboration & 2 & 3,4 & 5 & 3,46 \\
Clarity & 2 & 3 & 5 & 3,33 \\
Comprehensiveness & & & & \\
Completeness & 1 & 3,2 & 5 & 3,06 \\
Effective Management and capability development & 1 & 3 & 5 & 3,00 \\
Clarity & 1 & 3 & 5 & 3,00 \\
Comprehensiveness & & & & \\
Completeness & & & \\
Effective Performance measurement & & & \\
\hline
\end{tabular}


Table 3 Conceptual Model Evaluation Results (continued)

\begin{tabular}{|c|c|c|c|c|}
\hline The elements of conceptual framework & Min & Average & $\operatorname{Max}$ & De-Fuzzy \\
\hline Clarity & 1 & 3,2 & 5 & 3,06 \\
\hline Comprehensiveness & 1 & 3 & 5 & 3,00 \\
\hline Completeness & 1 & 3 & 5 & 3,00 \\
\hline \multicolumn{5}{|l|}{ Three approaches outcomes of ISA } \\
\hline \multicolumn{5}{|l|}{ Intellectual capital } \\
\hline Clarity & 2 & 3,2 & 5 & 3,4 \\
\hline Comprehensiveness & 1 & 3 & 5 & 3 \\
\hline Completeness & 1 & 2,8 & 5 & 2,93 \\
\hline \multicolumn{5}{|l|}{ Learning Organization } \\
\hline Clarity & 2 & 3,6 & 5 & 3,53 \\
\hline Comprehensiveness & 1 & 3 & 5 & 3,00 \\
\hline Completeness & 2 & 3,2 & 5 & 3,4 \\
\hline \multicolumn{5}{|l|}{ Knowledge Management } \\
\hline Clarity & 2 & 3,4 & 5 & 3,46 \\
\hline Comprehensiveness & 2 & 3,4 & 5 & 3,46 \\
\hline Completeness & 2 & 3,2 & 5 & 3,4 \\
\hline \multicolumn{5}{|c|}{ Knowledge Transfer for Knowledge capability } \\
\hline \multicolumn{5}{|l|}{ Human capital } \\
\hline Clarity & 2 & 3,4 & 5 & 3,46 \\
\hline Comprehensiveness & 2 & 3,4 & 5 & 3,46 \\
\hline Completeness & 1 & 3 & 5 & 3,00 \\
\hline \multicolumn{5}{|l|}{ Knowledge and know how } \\
\hline Clarity & 2 & 3,4 & 5 & 3,4 \\
\hline Comprehensiveness & 2 & 3,4 & 5 & 3,46 \\
\hline Completeness & 1 & 3 & 5 & 3,00 \\
\hline \multicolumn{5}{|l|}{ Innovation and Technology } \\
\hline Clarity & 2 & 3,4 & 5 & 3,46 \\
\hline Comprehensiveness & 2 & 3,4 & 5 & 3,46 \\
\hline Completeness & 2 & 3,4 & 5 & 3,46 \\
\hline
\end{tabular}

\section{CONCLUSION}

The results of our study contribute to a better understanding of ISAs in the upstream oil and gas sector that enhance the knowledge capability of partnering companies such as the NIOC. The proposed framework shows how knowledge transfers take place between emerging countries' firms and IOCs from developed countries under the ISA framework. The framework was tested and modified in two rounds using the Delphi method. The results show that the ISA formation and 
effective knowledge management can develop the NIOC's knowledge capability. The final framework confirmed by experts is shown in Figure 2. The experts emphasized the hierarchical structure of the first part of the model. They indicated consensus that some of these elements are fundamental and play an essential role in comparing the other factors. Partner selection and effectiveness of agreement are the first priorities for NIOC in order to sustain the desired and long-term outcomes of ISA. Moreover, for the outcomes part of the model, they proposed a schema with three fundamental elements. The positive feedback considered in the framework was not confirmed by the experts because more contributors need to be considered to demonstrate the relationships and dynamics of the results.

Our principal hypothesis that is explained by the conceptual framework proposes that "strategic alliances have a positive effect on developing knowledge capability," especially in high-tech sectors like the upstream oil and gas industry. We elaborated on the main factors of the model in round one and then, in the second round, used a questionnaire to validate the model in terms of completeness, clearance and comprehensiveness (three "Cs") of the model. Knowledge-based activities are at the genesis of a sustainable competitive advantage in today's economy. Researchers have asserted that firms should focus on the creation and accumulation of knowledge-based competencies in order to yield sustainable competitive advantages. Fostering ISAs between IOCs and the NIOC can enhance the organizational knowledge capabilities in terms of innovation, product development, intellectual capital and human resource development as well as trickle-down effects to related sectors and industries. The research demonstrates the importance of proper knowledge management to benefit from ISAs. The main limitation of this study is that it was conducted based on prior literature and perceptual validation through the fuzzy Delphi method. Future studies using empirical data from alliance partners in the ISA framework to test our proposition would be interesting.

Moreover, determining the ownership share of partners with MODM (MultiObjective Decision Making) approach with the neural network (Kimiagari et al.,2010), ranking International strategic Alliance project delaying factors (Iranmanesh et al,. 2007), ranking the stakeholder(s) involvement challenges in International strategic alliance project (Kimiagari et al,. 2013) and considering market strategy for international strategic alliance partner selection (Kimiagari et al,. 2015) also can be proposed for future study. 


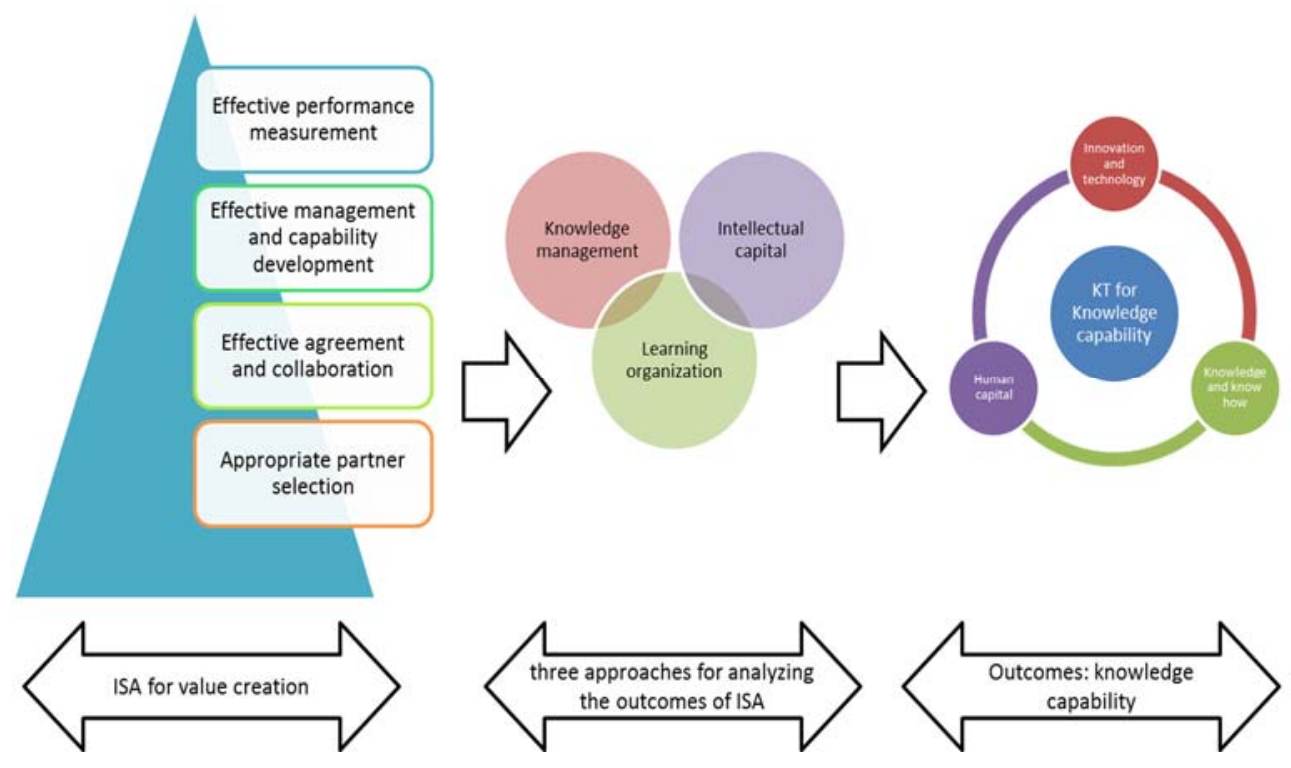

Figure 2 The Final Framework

\section{REFERENCES}

Al-Azad, M. S., Mohiuddin, M., \& Rashid, M. M. (2010). Knowledge transfer in offshore outsourcing and international joint-ventures (ijvs): A critical literature review from cross-cultural context. Global Journal of Strategies and Governance, $1(1), 41-67$.

Aigboduwa, J. E., \& Oisamoje, M. D. (2013). Promoting small and medium enterprises in the nigerian oil and gas industry. European Scientific Journal, 9(1). Anand, B., \& Khanna, T. (2000). Do firms learn to create value? The case of alliances. Strategic management journal, 21(3), 295-315 http://dx.doi.org/10.1002/(SICI)1097-0266(200003)21:3<295::AIDSMJ91>3.0.CO;2-O

Bacon, J., \& Fitzgerald, B. (1996). The field of IST: a name, a framework and a central focus. Executive Systems Research Center Working Paper Series, 96(5), $1-35$.

Badaracco, J. (1991). The knowledge link: How firms compete through strategic alliances. Harvard Business Press.

Baldi, F. (2013). Bidding for a Strategic Alliance in Good Times: The Case of Chevron-Petroleos de Venezuela SA. In Options in Alliances, 73-79. Springer Milan. http://dx.doi.org/10.1007/978-88-470-2850-0_8

Carayannis, E. G., Alexander, J., \& Ioannidis, A. (2000). Leveraging knowledge, learning, and innovation in forming strategic government-university-industry 
(GUI) R\&D partnerships in the US, Germany, and France. Technovation, 20, 477-488. http://dx.doi.org/10.1016/S0166-4972(99)00162-5

Carrillo, P., \& Chinowsky, P. (2006). Exploiting knowledge management: The engineering and construction perspective. Journal of Management in Engineering, 22(1), 2-10.

http://dx.doi.org/10.1061/(ASCE)0742-597X(2006)22:1(2))

Chen, C. J., \& Huang, J. W. (2009). Strategic human resource practices and innovation performance-The mediating role of knowledge management capacity. Journal of Business Research, 62(1), 104-114. http://dx.doi.org/10.1016/j.jbusres.2007.11.016

Chew, B. C. (2006). Technology transfer in malaysian high technology industry. Institute Of Technology Management And Entrepreneurship, National Technical University, College Of Malaysia.

Child, J., \& Faulkner, D. (1998). Strategies of Co-operation: Managing Alliances. Oxford: Networks and Joint Ventures Oxford University Press.

Cohen, W. M., \& Levinthal, D. A. (1990). Absorptive capacity: a new perspective on learning and innovation. Administrative science quarterly, 35, 128-152. http://dx.doi.org/10.2307/2393553

Contractor, F. J., \& Lorange, P. (2002). The growth of alliances in the knowledge based economy. International Business Review, 11, 485-502. http://dx.doi.org/10.1016/S0969-5931(02)00021-5

Das, T. K., \& Teng, B. S. (2000). A resource-based theory of strategic alliances. Journal of Management, 26(1), 31-61. http://dx.doi.org/10.1177/014920630002600105

Davenport, T. H., \& Prusak, L. (1998). Working knowledge: How organizations manage what they know. Harvard Business Press.

Davis, R., \& Thomas, L. G. (1993). Direct estimation of synergy: a new approach to the diversification-performance debate. Management Science, 39(11), 1334-1346. http://dx.doi.org/10.1287/mnsc.39.11.1334

Dehkordi, A. M., Farsi, J. Y., \& Piran, M. (2014). Assessment of technology transfer models in upstream oil industry and choosing the best applicable model for iran (Case Study: Agha-jari Oil \& Gas Production Co.). Asian Journal of Research in Business Economics and Management, 4(1), 264-279.

Devlin, G., \& Bleackley, M. (1988). Strategic alliances-guidelines for success. Long Range Planning, 21(5), 18-23. http://dx.doi.org/10.1016/0024-6301(88)90101-X 
Eisenhardt, K., \& Schoonhoven, C. B. (1996). Resource-based view of strategic alliance formation: strategic and social effects in entrepreneurial firms. Organization Science, 7(2), 136-150 http://dx.doi.org/10.1287/orsc.7.2.136

Emdena, Z., Yaprakb, A., \& Cavusgila, T. (2005). Learning from experience in international alliances: antecedents and firm performance implications. Journal of Business Research, 883-892. http://dx.doi.org/10.1016/j.jbusres.2003.10.008

Ernst, D., \& Bamford, J. (2005). Your alliances are too stable. Harvard Business Review, 83(6), 133-141.

Ernst, D., \& Steinhubl, A. M. J. (1997). Alliances in upstream oil and gas. The McKinsey Quarterly, 144-155.

Geringer, J. (1991). Strategic determinants of partner selection criteria in international joint ventures. Journal of International Business Studies 22(1), 41-62. http://dx.doi.org/10.1057/palgrave.jibs.8490291

Geringer. J. M. (1988). Joint venture partner selection: strategies for developed countries. Westport, CT: Quorum Books.

Glaister, K. W., \& Buckley, P. J. (1999). Performance relationships in UK international alliances. Management International Review, 39(2), 123-47.

Gnyavali, D. R., \& Grant J. H. (1997). Enhancing corporate venture performance through organizational learning. International Journal of Organization Analysis, 5(1):74-98. http://dx.doi.org/10.1108/eb028863

Grant, R. M. (2013). The development of knowledge management in the oil and gas industry. Universia Business Review, (40), 92-125.

Hafeez, K., Malak, N., \& Zhang, Y. (2007). Outsourcing non-core assets and competences of a firm using analytic hierarchy process. Computers \& Operations Research, 34(12), 3592-3608. http://dx.doi.org/10.1016/j.cor.2006.01.004

Hagedoorn, J., \& Sadowski, B. (1999). The transition from strategic technology alliances to mergers and acquisitions: an exploratory study. Journal of Management Studies, 36(1), 87-107. http://dx.doi.org/10.1111/1467-6486.00127

Hansen, M.T., Nohria, N., \& Tierney, T. (1999). What's your strategy for managing knowledge? Harvard Business Review, 77(2), 106-116.

Hennart, J. R., \& Larimo, J (1998). The impact of culture on the strategy of multinational enterprises: Does national origin affect ownership decisions? Journal of International Business Studies, 29(3), 515-538.

Hermans, R., \& Kauranen, I. (2005). Value creation potential of intellectual capital in biotechnology-empirical evidence from Finland. R\&D Management, 35(2), 171185. http://dx.doi.org/10.1111/j.1467-9310.2005.00381.x 
Hussi, T. (2004). Reconfiguring knowledge management-combining intellectual capital, intangible assets and knowledge creation. Journal of Knowledge Management, 8(2), 36-52. http://dx.doi.org/10.1108/13673270410529091

Iranmanesh, H., Mojir, N., \& Kimiagari, S. (2007). A new formula to "Estimate At Completion" of a Project's time to improve "Earned value management system". In Industrial Engineering and Engineering Management, 2007 IEEE International Conference (p.1014-1017). IEEE. http://dx.doi.org/10.1109/IEEM.2007.4419345

Ishikawa, A., Amagasa, M., Shiga, T., Tomizawa, G., Tatsuta, R., \& Mieno, H. (1993). The max-min delphi method and fuzzy delphi method via fuzzy integration. Fuzzy Sets and Systems, 55, 241-253. http://dx.doi.org/10.1016/01650114(93)90251-C

Iyer, K. N. (2002). Learning in strategic alliances: an evolutionary perspective. Academy of Marketing scince Review, 10(1), 1-14.

Jegede, O.O., Ilori, M. O., Sonibare, J. A., Oluwale, B. A., \& Siyanbola, W.O. (2013). Knowledge sharing and innovation as it affects the local content in the oil and gas industry in nigeria. African Journal of Science, Technology, Innovation and Development, 5(1), 31-38. http://dx.doi.org/10.1080/20421338.2013.782145

Kale, P., Singh, H., \& Bell, J. (2009). Relating well: Building capabilities for sustaining alliance networks. In P. Kleindorfer \& Y. Wind (Eds.), The network challenge: Strategies for managing the new interlinked enterprise. London: Pearson Press.

Kale, P., Singh, H., \& Perlmutter, H. (2000). Learning and protection assets in strategic alliances: building relation capital. Strategic management Journal, 21, 217-237. http://dx.doi.org/10.1002/(SICI)1097-0266(200003)21:3<217::AIDSMJ95>3.0.CO;2-Y

Karuranga, E., Asti, F., Musonera, E., \& Mohiuddin, M. (2011). The impact of foreign direct investment on financial performance: results from the M\&A experiences of canadian firms from 1999 to 2005. International Review of Business Research Papers, 7(4), 25-45.

Khamseh, H. M., \& Jolly, D. R. (2008). Knowledge transfer in alliances: determinant factors. Journal of Knowledge Management, 12(1), 37-50. http://dx.doi.org/10.1108/13673270810852377

Kiessling, T. S., Richey, R. G., Meng, J., \& Dabic, M. (2009). Exploring knowledge management to organizational performance outcomes in a transitional economy. Journal of World Business, 44(4), 421-433. http://dx.doi.org/10.1016/j.jwb.2008.11.006 
Kimiagari, A. M., Jasemi, M., \& Kimiagari, S. (2010). A modern neural network model to do stock market timing on the basis of the ancient investment technique of Japanese candlestick. In Proceedings of the 21st IASTED International Conference (p165). http://dx.doi.org/10.1016/j.eswa.2010.09.049

Kimiagari, S., Keivanpour, S., Mohiuddin, M., \& Van Horne, C., (2013). The cooperation complexity rainbow: Challenges of stakeholder involvement in managing multinational firms. International Journal of Business and Management, 8 (22), 50-64. http://dx.doi.org/10.5539/ijbm.v8n22p50

Kimiagari, S., Gabrielsson, P., Gabrielsson, M., \& Montreuil, B. (2015). 5. Market strategy of international new ventures originating from a small and open economy. Handbook of Research on International Entrepreneurship Strategy: Improving SME Performance Globally, 85-103. http://dx.doi.org/10.4337/9781783471584

Kotabe, M., \& Swan K. S. (1995). The role of strategic alliances in high-technology new product development. Strategic Management Journal, 16(8), 621-636. http://dx.doi.org/0.1002/smj.4250160804

Kriščiūnas, K., \& Daugèlienè, R. (2006). The assessment models of knowledge-based economy penetration. Engineering economics, 5(50), 36-46.

Kumar, S., \& Malegeant, P. (2006). Strategic alliance in a closed-loop supply chain, a case of manufacturer and eco-non-profit organization. Technovation, 26(10), 1127-1135. http://dx.doi.org/10.1016/j.technovation.2005.08.002

Lane, P. J., Salk, J. E., \& Lyles, M. A. (2001). Absorptive capacity, learning, and performance in international joint ventures. Strategic Management Journal, 22, 1139-1161. http://dx.doi.org/10.1002/smj.206

Lee, Y., \& Cavusgil, S. T. (2006). Enhancing alliance performance: The effects of contractual based versus relational-based governance. Journal of Business Research, 59(8), 896-905. http://dx.doi.org/10.1016/j.jbusres.2006.03.003

Lyles, M. A., \& Salk, J. E. (1996). Knowledge acquisition from foreign parents in international joint ventures: an empirical examination in the Hungarian context. Journal of International Business Studies, 27(5), 877-903.

Managi, S., Opaluch, J. J., Jin, D., \& Grigalunas, T. A. (2005). Environmental regulations and technological change in the offshore oil and gas industry. Land Economics, 81(2), 303-319. http://dx.doi.org/10.3368/le.81.2.303

Mohiuddin, M., \& Su, Z. (2014). Global value chains and the competitiveness of canadian manufacturing SMEs. Academy of Taiwan Business Management Review 10(2), 82-92. 
Mohiuddin, M., \& Su, Z. (2013). Manufacturing small and medium size enterprise's offshore outsourcing and competitive advantage: an exploratory study on canadian offshoring manufacturing SMEs. Journal of Applied Business Research, 29(4), 1111-1130.

Nielsen, B. B. (2005). The role of knowledge embeddedness in the creation of synergies in strategic alliances. Journal of Business Research, 58(9), 1194-1204. http://dx.doi.org/10.1016/j.jbusres.2004.05.001

Nonaka, I., \& Takeuchi, H. (1995). The knowledge-creating company: How Japanese companies create the dynamics of innovation. Oxford university press.

Pedlar, M. (1991). Action Learning in Practice. 2nd ed., Gower, Aldershot.

Powell, W. W., Koput, K. W., \& Smith-Doerr, L. (1996). Interorganizational collaboration and the locus of innovation: Networks of learning in biotechnology. Administrative science quarterly, 41(1), 116-145. http://dx.doi.org/10.2307/2393988

Reichers, A. E. (1985). A review and reconceptualization of organizational commitment. Academy of Management Review, 10(3), 465-476. http://dx.doi.org/10.5465/AMR.1985.4278960

Sasson, A., \& Blomgren, A. (2011). Knowledge Based Oil and Gas Industry. Research Report 3/2011, BI Norwegian business School.

Senge, P. M. (1990). The Fifth Discipline: The Art and Practice of the Learning Organization. New York, NY: Doubleday Currency.

Sinkula, J. M., Baker, W. E., \& Noordewier, T. A. (1997). Framework for marketbased organizational learning: linking values, knowledge, and behavior. Journal of Academic Market Science, 25(4), 305-318. http://dx.doi.org/10.1177/0092070397254003

Sinkula, J. M. (1994). Market information processing and organizational learning. Journal of Marketing, 58(1), 35-45. http://dx.doi.org/10.2307/1252249

Linstone, H. A., \& Turoff, M. (2002). The Delphi Method. Techniques and applications, 53.

United Nations Country Readiness Assessment Report (2002). Towards A Knowledge based Economy Armenia United Nations Economic Commission for Europe New York and Geneva.

Watkins, K., \& Marsick, V. (1992). Building the learning organisation: a new role for human resource developers. Studies in continuing education, 14(2), 115-129. http://dx.doi.org/10.1080/0158037920140203

Williamson, O. E. (1985). Assessing contract. Journal of Law, Economics, and Organization, 1, 177-208. 
